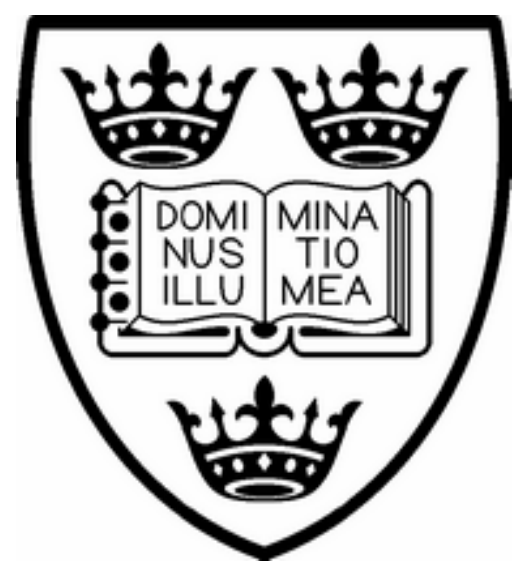

U N IVER S I T Y O F OXFORD

Discussion Papers in Economic and Social History

Number 60

(revised version, October 2007)

\begin{abstract}
THE MARKUP FOR LEMONS:
QUALITY AND UNCERTAINTY

IN AMERICAN AND BRITISH

USED-CAR MARKETS c.1953-1973
\end{abstract}

AVNER OFFER

U N I ER I T Y OF OXFORD 
For a full list of University of Oxford

Discussion Papers in

Economic and Social History

see pages $36-39$

(C) Avner Offer, 2007 


\title{
THE MARKUP FOR LEMONS: QUALITY AND UNCERTAINTY \\ IN AMERICAN AND BRITISH \\ USED-CAR MARKETS c.1953-1973*
}

\author{
AVNER OFFER \\ All Souls College (University of Oxford) \\ High Street \\ Oxford OX1 4AL \\ United Kingdom \\ avner.offer@all-souls.ox.ac.uk \\ tel. $+44-1865-279348$
}

[contains data appendix not included in published version, Oxford

Economic Papers, vol. 59, 5, Supplementary issue (2007), pp. i31-i48]

\footnotetext{
* Thanks to Annie Chan, Harriet Jackson, Maïa-Laura Ibsen, and Siobhan McAndrew for painstaking data collection; to Gavin Cameron, Paul David, Charles Feinstein, Siobhan McAndrew, Mara Meacci, Raphael Schapiro, Peter Temin, and seminar participants at Oxford, for helpful advice; to John Muellbauer for acute comments and for suggesting the title.
} 


\begin{abstract}
Automobile depreciation rates and dealer markups in the United States and Britain during the 1950s and 1960s provide evidence on the effect of asymmetric information on market structures. Initial depreciation was not exceptional, and trade was not disabled. The risk of asymmetric information was not large, and was largely covered by dealer warranties. Adverse selection kicked in as cars aged: markups increased and fixed selling costs caused dealers to withdraw from trading older cars. Despite their lower quality, British makes depreciated less, probably due to different novelty signals and longer styling cycles.
\end{abstract}




\section{Introduction}

From time to time one hears either mention of or surprise at the large price difference between new cars and those which have just left the showroom. Why do cars lose so much of their value as soon as they are sold? George A. Akerlof's explanation is well known - an almost-new car offered for sale is likely to be a 'lemon', and is discounted accordingly: "most cars traded will be the "lemons", and good cars may not be traded at all. The "bad" cars tend to drive out the good' (Akerlof, 1970, p. 489). This has entered the conventional wisdom: a popularizing economics book has as its sub-title 'Why you can never buy a decent used car!' (Harford, 2005). ${ }^{1}$

The argument is intrinsically compelling, although originally no evidence was provided to support it. It is not easy to test. It is consistent with three different outcomes: no trading, exceptional discounting, and trading facilitated by dealer warranties (Akerlof, 1970, pp. 489, 499). Indeed, the insight does not depend for its validity on the realities of the used car market, which only serve as a plausible metaphor (Sugden, 2000). Nevertheless, it is useful to investigate reality, if only as a reminder that it does not always support compelling models. In this paper, some evidence of used-car markets is examined. It suggests that while Akerlof's insight retains its power, it is not securely founded on the realities of the car market.

Several empirical studies have attempted to test the argument in the automobile market (Bond, 1982, 1984; Lacko, 1986; Genesove, 1993; Porter and Sattler, 1999; Emons and Sheldon, 2002). All of them have concentrated on adverse selection in vehicles that are typically more than a year old, and mostly older than that. Overall, they have found the evidence of adverse selection to be absent, or at best, weak. ${ }^{2}$ The existence of a large private market in second-hand cars also suggests that the risk of 'lemons' was not in itself sufficient to inhibit trade seriously in cars at any age.

Arguably, however, these are not tests of Akerlof's own example. In what sense can used cars be described as 'lemons'? Nobody expects an older used car to be 'as good as new'. Some wear and tear is expected, and it is not obvious that post-purchase repairs arise from 'pre-existing conditions' which were known to sellers in advance. The tests were typically rather weak ones, which categorized lemons as cars that required more repairs (or that were sold more fre-

\footnotetext{
${ }^{1}$ Omitted in the British edition.

2 In contrast, theoretical studies argue that adverse selection ought to exist (Kim, 1985; Hendel and Lizzeri, 1999).
} 
quently), and attempted to identify some prior indicator (usually the credibility of the seller) that might identify them and indicate prior asymmetric information.

Akerlof's category of automobile lemons is more demanding. These are cars fresh out of the showroom. They ought to be 'as good as new', and any serious defects ('lemons') cannot be attributed to wear and tear. Such cars are born defective. Akerlof posits that either there will be no trade in such cars, that they will trade at a severe discount, or that dealer warranties will facilitate trade. What is needed is a test of depreciation of almost-new cars. Akerlof's stylized fact is that such cars suffer (in principle) from exceptional depreciation because of this undetectable risk. But such a risk is almost entirely hypothetical, since such cars were covered by factory warranties. The hapless buyer could take the car back to the vendor, and had little incentive to pass the problem on to another buyer. In other words, Akerlof's risk was covered by the factory warranty. This makes sense: the factory (or a dealer, for older cars) was much better placed to absorb this risk than any private individual, and was able to take measures to prevent it.

If lemons were uncommon (a possibility not considered by Akerlof), then they would have little impact on prices. If the risk were a large one, it might be captured in the size of exceptional factory markups, reflecting the cost of making such defects good. Alternatively, if one thinks that 'once a lemon always a lemon', then the risk ought to continue to impinge on the price of cars before any serious wear and tear takes place, e.g. during their first year. In particular, this would be the case before 1960 in the USA, when factory warranties only ran for three months. This is worth testing for, especially since several studies appear to have found evidence for exceptional price declines during the first year. The present study finds very little evidence in car prices for adverse selection either in initial factory markups, or at the age of one year. On the contrary, our evidence suggests that the large price difference between the retail value of a car, and its potential selling value to the buyer, was not unique to new cars, and was not exceptionally large. It was actually lower in relative terms for new cars, because the risk of invisible defects increased as cars aged.

For relatively new used cars, i.e. not older than four or five years, the risk of mechanical 'lemons' was more often borne by dealers than by customers. The important role of dealers is usually neglected (Hendel and Lizzeri, 1999, p. 1113). But selling cars is a very large industry in its own right. In 1958 for example, comparable numbers of people (more than 600,000) worked to sell and support cars in the USA, and to make them. ${ }^{3}$ All vintages were actively traded:

3668,000 worked for dealers (including the proprietors) and 640,000 for manufacturers in 1958 (Automobile Manufacturers Association, 1961, pp. 38, 67). 
but in different types of transactions, which reflected the different risks of adverse selection. New cars were guaranteed by the factory. Older cars were normally provided with some warranty by dealers, though there was no standard practice, and warranty periods were short (Northwood Institute, 1967, p. 169170).

As mechanical quality declined with the age of cars, the relative (but not necessarily the absolute) cost of providing a warranty increased. This is captured in rising dealer markups for older cars. In consequence of inelastic fixed costs, fullservice dealers withdrew from trading older cars, and transferred the risk to private buyers.

Another source of depreciation was styling and mechanical innovation, which could make older models relatively less attractive. This is studied here by comparing American and British models. British cars depreciated less than American ones, despite their inferior mechanical quality. More intensive styling innovation in the United States threatened owners with rapid stylistic obsolescence.

These issues are investigated with samples of American and British car prices in the 1950s and the 1960s. This period mostly antedates Akerlof's article, and matches the dynamics of car pricing of his time more closely than would a study of current prices. ${ }^{4}$ It stops at the oil crisis of 1973, a turning point for car marketing and design. Our conclusion is that it was usually possible to find a good used car, and if one wanted the extra assurance, to buy it with a dealer's warranty.

${ }^{4}$ Pashigian et al. (1995) have shown that these dynamics are not stable over time. 


\section{The Argument}

An initial exceptionally steep decline in used-car prices is commonly treated as an established fact. Akerlof's 'usual lunch table justification' for it (the case he needed to rebut) was the exhaustion of a novelty premium attributed to 'the pure joy of owning a new car'. Akerlof's article did not extinguish this argument. Frank C. Wykoff argued that new cars were a 'superior good' with exceptional 'freshness', novelty and reliability (Akerlof, 1970, p. 490; Wykoff, 1973, p. 388). Used cars were not credible substitutes for new ones (Smith, 1975, pp. 4-5; Porter and Sattler, 1999). In 1973, Wykoff wrote that 'new cars depreciated at almost twice the rate of used cars ... after the first year cars appeared to depreciate at a constant rate.' In 1989 he was more precise: 'First-year depreciation ranges from 35 percent to 40 percent. Second-year depreciation is about 20 percent and depreciation is approximately constant thereafter.' To Howard Rachlin and Andres Ranieri, the initial steep decline suggested hyperbolic discounting (Wykoff, 1973, p. 379; Wykoff, 1989, p. 260; Rachlin and Ranieri, 1992, p. 96). Indeed, such a kinked curve is analogous to the 'quasi-hyperbolic' discount curve (steep in the first period, flatter in subsequent ones) which has been adopted in studies of time-inconsistency (Laibson et al., 2003, p. 520-2).

In fact, our evidence shows that the initial decline was not exceptionally steep, but was comparable to (and mostly lower than) the annual decline in subsequent years. The reason for the perception of a steep initial decline is mundane. Car dealers offered two sets of prices: one was the price at which they sold (the 'retail' price), the other at which they bought (the 'wholesale' one). ${ }^{5}$ There were two separate depreciation vectors, one for retail prices, and one for wholesale prices. The steep decline in car prices at the outset was simply the shifting of the car's price downwards from the retail to the wholesale schedule, combined with the normal depreciation over time. This is shown schematically in Fig. 1.

In Fig. 1, the difference between the retail and wholesale price vectors at any time makes up the dealer markup. This explanation of initial price declines does not invalidate Akerlof's insight of adverse selection, but rather it demonstrates the cost of one of his proposed solutions, the dealer warranty. The dealer markup covered both the core cost of selling cars, and the cost of a warranty for

${ }^{5}$ New wholesale prices were not reported. (National Automobile Dealers' Association, 195773; Glass's Guide Services Limited, 1968-73) 
Fig. 1. Schematic depreciation schedules of passenger cars

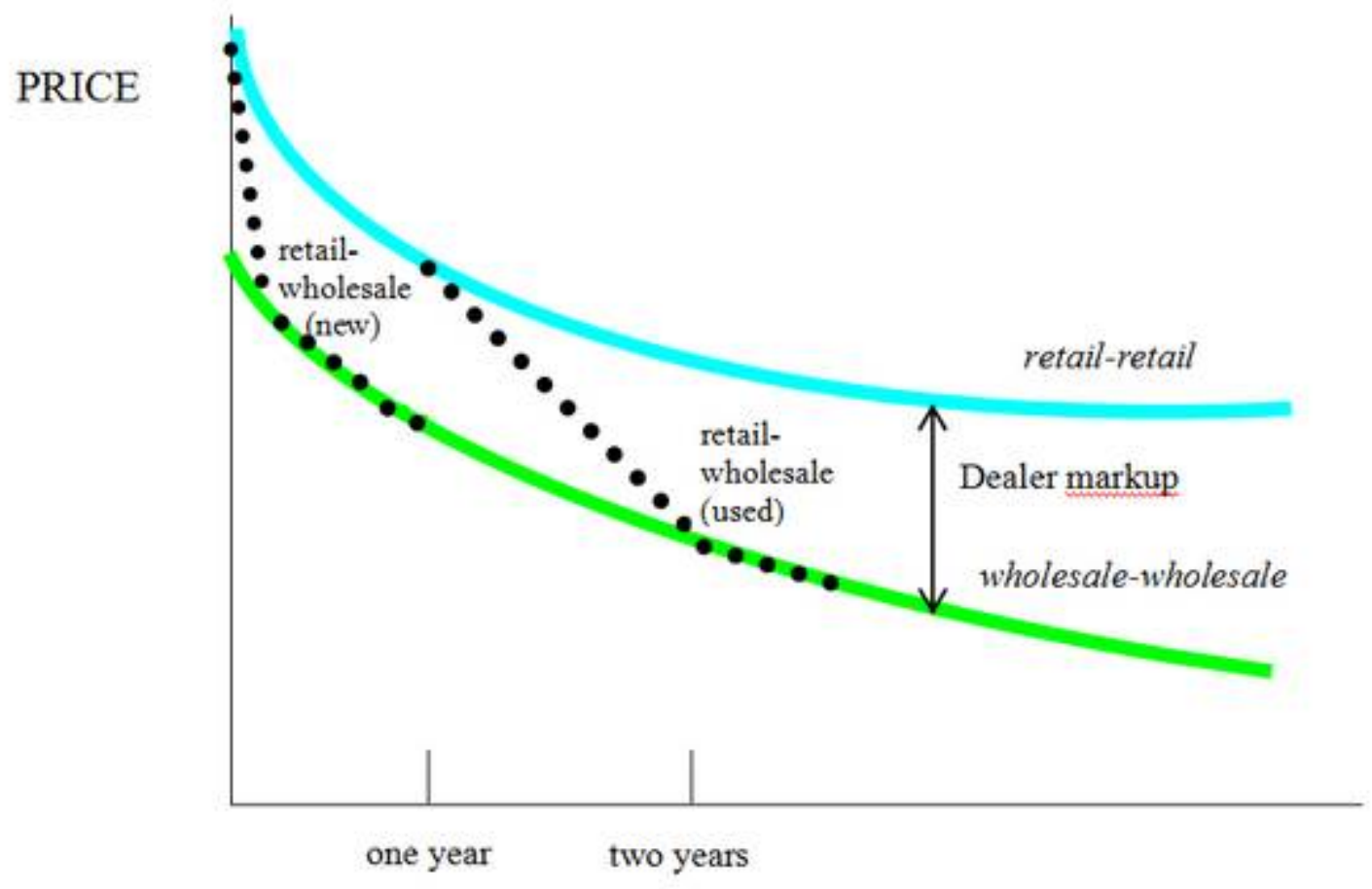

AGE OF CAR

older cars (not covered by the factory). Selling entailed a range of costly services: finance and storage of retail stock and spare parts, transport, advertising, display, negotiation, trade-in, finance and insurance, and service facilities (Harless and Hoffer, 2002, p. 272-4). In the 1960s, dealers reported that about 73 percent of their selling costs were fixed, i.e. covered labour and premises. ${ }^{6}$ The warranty cost was not necessarily incurred ex-post, but was more commonly the pre-sale cost of reconditioning (Northwood Institute, 1967, p. 153-6; Lacko, 1986).

Once the car was sold, the value to the buyer of these dealer services was largely exhausted, and could not be passed on to any new buyer. Its resale value (the 'wholesale' price, at which a dealer would repurchase) only represented the intrinsic services embodied in the car, such as conveying passengers, signalling status, and sensual pleasure.

For new car buyers, the risk of 'lemons' was covered by the factory warranty. For used cars, the cost of explicit or implicit warranties was largely borne by the dealer, either the risk of purchasing a lemon himself, or that of meeting customer claims. This gave the factory a strong incentive to avoid lemons. When a used

6 Calculated from 'Auto Dealers Sales Expense and Operating Profit Before Federal Income Tax’, (Ward's Reports (1960-1966)). 
car was offered in trade-in, it was either disposed of immediately, or it was tested, and then reconditioned to merchantable quality before being sold at retail. Dealers had sufficient knowledge of the market to understand the risks and rectify them (Northwood Institute, 1967, ch. 6; Genesove, 1993). In one survey, warranties added about 10 percent to the cost of a used car, but 'average quality did not differ between warranted and unwarranted cars.' Warranties could be seen as insurance for worried customers, but not as a signal of quality (Lacko, 1986, p. 64). Both our evidence of one-year-old cars, and other studies of older cars, does not suggest any wide prevalence of 'lemons'.

Private sellers and private buyers could sometimes negotiate a better price with each other than with dealers, by forgoing the warranty element. That is acknowledged in British car price manuals, which have often included columns for private sales, with prices intermediate between dealers' retail and wholesale prices (e.g. Parker, 1996). In Lacko's 1979-80 sample, there was no difference in price, and no quality differences, between such cars sold privately and those sold by dealers (for cars less than eight years old). A small majority of cars were traded privately, suggesting that adverse selection was not a serious problem (Lacko, 1986). Dealers were advised to monitor private-sale ad prices on a daily basis as a guide to the market (Northwood Institute, 1967, p. 162).

In a competitive market the size of the markup can be taken as a measure of the cost of selling, including quality assurance. Our first argument is already stated: (i) Initial depreciation was not exceptional. Subsequently over the period of a car's life, we make these further hypotheses: (ii) The dealer markup on used cars should be larger than on new ones, since the risk was now borne by the dealer, not the manufacturer, and markups should increase with age as selling costs were inelastic (iii) Makes with a good reputation for quality might have lower depreciation and markups. (iv) In addition, but separately, frequent restyling would be associated with higher depreciation, since it increased uncertainty about the fashion value of older cars. These hypotheses are investigated below. 


\section{Evidence}

Our quantitative evidence consists exclusively of car prices. Observations are annual. American used car prices are derived from the monthly National Automobile Dealers Association, Official Used Car Guide, Eastern edition (NADA). This was compiled from regular transaction price reports of member dealers and from auction sales reports, and may be regarded as sample means of the larger population of dealer and auction transactions (NADA; Northwood Institute, 1967, p. 156). Prices were taken from the January or February issues, and reflected the first quarter of the model year, which began in October. ${ }^{7}$ This sampling date maximizes the novelty effect on prices, and reduces ambiguity about the precise age of year-old cars. The British motor industry was not comparable during the 1950s, when it expanded rapidly after post-war shortages. By the 1960s growth had levelled off, and cycles were similar to American ones (Foreman-Peck et al., 1995, table 4.1, p. 94). The British source, Glass's Guide, was similar to the American one, but covered the whole country. New-car prices in the USA included federal taxes, and purchase taxes in Britain. At one-third of the new price, British taxes were about three times as high as American ones. Unlike American cars, British models might be modified at any time, but starting in 1963, the vintage was indicated by means of a letter on the licence plate, which changed every January. In 1967, the new-year letter date was moved to August. Glass continued to take its representative car as being 'first registered in the spring', and the sampling month is April throughout. ${ }^{8}$ In both manuals, used cars are defined as being in good condition, but that does not exclude opportunistic behaviour, since 'lemons' were by definition not easily detectable (Northwood Institute, 1967, p. 157; Genesove, 1993, pp. 646-7).

For new cars, suggested retail prices are used, as quoted in NADA and Glass. New car list prices could be discounted substantially, and actual transaction prices are not available. ${ }^{9}$ But USA Ford staff calculated in 1958 that customer discounts were offset by delivery costs and state taxes. Hence the list price is a reasonable proxy for the actual new-car transaction price at that time. ${ }^{10}$ List

\footnotetext{
${ }^{7}$ Buick 1969 models, from December 1968. Prices included heater and radio. This source is difficult to obtain. A single run, starting in 1957, was located at the New York Public Library.

${ }^{8}$ Following practice in the motor trade (Glass's Guide, Nov. 1969, pp. 2-4, cited from p. 4, col. 5). Thanks to S. McAndrew for this reference.

9 Pashigian (1961, p. 37), and Ward's Reports (1960, p. 123) report excess capacity after 1954.

10 On the basic 1958 Ford car. List price $\$ 1977$ from NADA, (Feb. 1958); transaction cost (\$1994) calculated from Ford Product Planning Office, Economy Car Report, Nov. 13 1957,
} 
prices placed a ceiling on transaction prices. Using them biases new prices upwards, i.e. in favour of Akerlof's argument: any lower actual price means that there is less of an initial discount to explain. In the Ford 1958 report, the dealer markup came to 12 percent of the list price, 13.6 percent of the factory wholesale price. Another estimate of new car markups (for the 1960s) places them higher, but provides no source. ${ }^{11}$ An authoritative source reported an average gross dealer markup of 14.7 percent of total sales (standard dev. 0.44) in 1960-66. ${ }^{12} \mathrm{In}$ 1987, dealer new car markups before discounts could range between 6 percent and 14 percent of list price (Harless and Hoffer, 2002, p. 271). Where new-car wholesale prices are quoted here, a 12 percent dealer markup is assumed.

The total number of depreciation observations is 4,032. Two different sampling frames are used, each repeated three times, on different samples. The first frame is a cross-section, sampling the 1957 prices of the four previous model vintages. The second frame is a panel, which follows the 1957 vintage as it aged over five subsequent years. The initial United States 1957 sample consisted of some 54 Ford and Buick models. The same makes were sampled again in 1968 (panel) and 1969 (cross-section). Concurrent British samples of 18 Ford and Morris models were also taken (1968 and 1969), as well as United States prices of the Volkswagen 'beetle' sedan (one model, 1964-1973) (table 1). ${ }^{13}$ This provides coverage from the early 1950s up to the early 1970s. Ford and Buick sold staple mass-market models, with distinctive positions in the USA status hierarchy, Ford as a 'low price' car, Buick as a 'medium priced' one. ${ }^{14}$ In Britain, the

Ford Industrial Archives AR-94-200777-5, fo.33; Product Planning Committee, 13 Nov. 1957, Ford Industrial Archives, AR-94-200777-6. The nominal list price (full dealer markup; state taxes and freight excluded) was $\$ 1935$. The original figures are adjusted to the NADA bare car price basis by removing optional accessories, and adjusting taxes and the reported dealer markup proportionally.

1118 percent of retail (17-25 percent of wholesale), increasing in price, and including more expensive cars. White (1971, p. 106).

12 Ward's Reports, 'Auto Dealers Sales Expense and Operating Profit Before Federal Income Tax', (1961-1967).

13 Sampling was constrained by the absence of data prior to 1957: the cross-section method gave access to earlier years. It was limited to four years (six in the UK) due to model attrition. In the panels, vehicles lost about 80 percent of their value after five years. 1968 (panels) and 1969 (cross-sections) were chosen in order to avoid 1967, when model year date indicators changed in Britain, and to fit in five panel years before 1973.

14 Offer (1998) discusses model hierarchies. The upmarket Ford Thunderbird model has been dropped. 
ranking was reversed, with Ford making more mid-market models. ${ }^{15}$ In the crosssection frame, each car belongs to a different vintage, and is likely to be somewhat different mechanically and stylistically. In the panels, cars are mechanically uniform throughout (except for wear and tear), but are observed at different ages.

TABLE 1

SAMPle MOdels, NeW CAR PRICES IN \$US (1957 PRICES)

\begin{tabular}{llccc}
\hline Year & Make & Mean & $\begin{array}{c}\text { Standard } \\
\text { Deviation }\end{array}$ & $\begin{array}{c}\text { No. of } \\
\text { models }\end{array}$ \\
\hline 1957 & Buick & 3379 & 508 & 19 \\
& Ford & 2330 & 183 & 35 \\
1969 & VW & 1495 & & 1 \\
& Buick & 2727 & 489 & 32 \\
& Ford & 2298 & 394 & 72 \\
& VW & 1340 & & 1 \\
& Morris UK & 1420 & 264 & 10 \\
& Ford UK & 1641 & 273 & 8 \\
\hline
\end{tabular}

15 Morris models were produced by the British Motor Corporation (British Leyland from 1968), which sold an identical 'Austin' line as well. 


\section{Depreciation}

If adverse selection was peculiar to new cars, then cars should have depreciated exceptionally during their first year. If not, they would have depreciated about the same as older cars, or even less. Our task here is simply to show that contrary to several claims in the literature, and to one possible interpretation of Akerlof, cars did not depreciate exceptionally during the first year. We provide what are essentially descriptive statistics. They do not attempt to explain precise depreciation changes from year to year (for which it would be appropriate to control for vintage, model, and time fixed effects), but merely to establish that depreciation levels were not exceptional in the first year. Contrary to the 'novelty value' hypothesis quoted in section 2 above, initial depreciation was in fact usually smaller than depreciation in subsequent years.

The main results are presented in Fig. 2. Three measures of depreciation are provided, retail to retail (RR), wholesale to wholesale (WW) and retail to wholesale $(\mathrm{RW})$. Of the three measures, the retail-to-wholesale depreciation rate (RW) comes closest to Akerlof's example of a car sold new by a retailer, and offered for sale soon afterwards privately. The gap between sale and resale in our case is a whole year from new - that is as close as the data allows us to get: prices for younger used cars are not quoted in the source, which suggests a thin market, though not necessarily for the reasons suggested by Akerlof. Typically, new cars will have lost 30 to 40 percent of their value in transit from the dealer to the purchaser during their first year. Such a large absolute loss on an almost-new car would in itself deter sellers from such drastic preference-reversal quite independently of any risk of 'lemons', even if they had a legitimate reason to change their minds and to sell so shortly after completing a major purchase. In any case, however, this loss was no greater in relative terms than the one incurred by a private individual when re-selling an older car immediately after buying it.

The cars that dealers sold (retail) were typically offered with some form of warranty, while those that dealers purchased (wholesale) were not. Most usedcar dealers accepted some responsibility for the higher-value cars they sold, though the warranty terms varied from dealer to dealer (Northwood Institute, 1967, p. 169-70). Retail-to-retail (RR) was depreciation of cars defined as being in good condition, without adverse selection. It simply measures the year-to-year depreciation of the retail offer price. Wholesale prices (WW - reported only in the appendix tables) represented a population of cars that included potential lemons, and therefore already embodied the risk of adverse selection undetectable by a dealer. Wholesale-to-wholesale depreciation rates were thus almost universally higher (though not always significantly) than retail-to-retail (see appendix tables 
A1-A2). Wholesale price depreciation simply captured the larger quality variance among used cars in private ownership, before testing and repair.

Fig. 2. Annual automobile mean depreciation rates by age, USA and UK

$($ Vertical $=$ depreciation rate; horizontal $=$ age in years $)$

Cross-sections

USA

1957

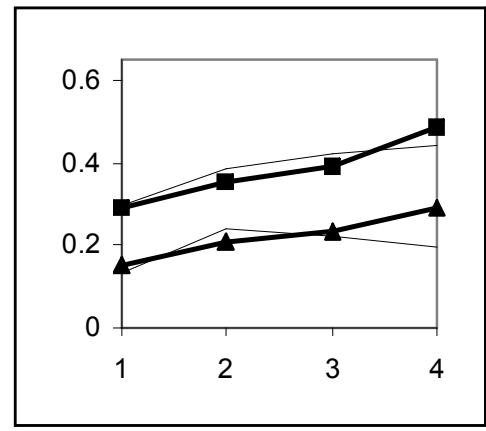

USA

$1968-9$

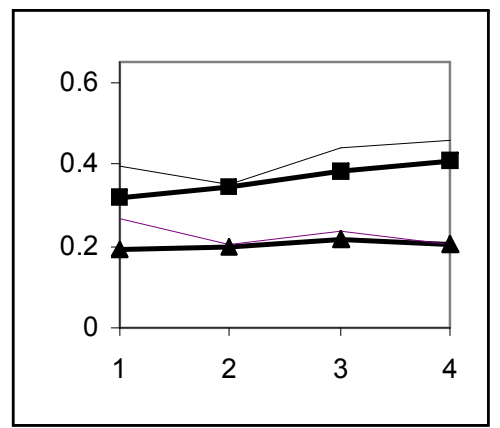

UK

$1968-9$

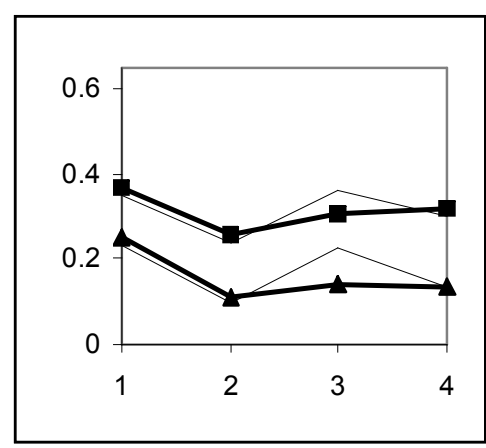

Retail-Wholesale (Buick or Morris)
Panels
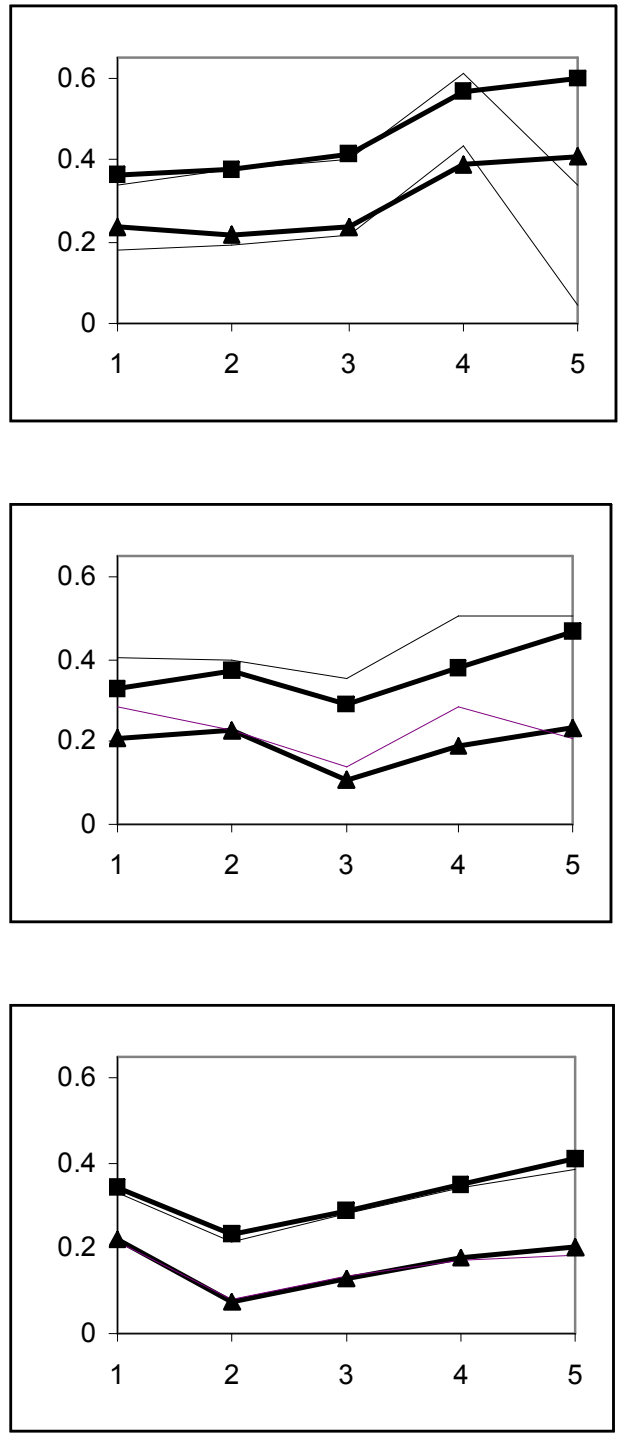

Ford $\leftarrow$ Retail-Retail (Buick or Morris)

Sources: Appendix, tables A1, A2 
Figure 2 shows that older cars depreciated no less than newer ones, and usually depreciated more. ${ }^{16}$ Without controlling for model, cohort and period attributes (for which adequate data were not available in this source), it is impossible to explain precisely the changes in depreciation rates. But our argument is about levels, not changes, and appears to be robust: whatever sampling frame is used, there is no evidence that initial depreciation rates were uniquely exceptional, and it would require an implausible set of confounding effects to reject this finding. In some years depreciation levels declined somewhat, but not enough to sustain the initial 'novelty value premium' argument. This is echoed in Wykoff's large sample of 1980s business-lease cars: he found an apparent 'lemon' effect only in one small section of his overall sample, the Oldsmobile Delta models. Their price at 18 months was higher than at six months. But the effect was weak, and suggests some issue particular to that model (Wykoff, 1989, p. 267, p. 289, n. 11).

In Britain, depreciation rates were higher during the first year than in the United States. In the second year they dropped sharply and only regained initial levels at age six (tables A1, A2, (c)). It would be rash to generalize from this. These UK year two values appear to be exceptional outliers, associated with the change in the new model licence plate date letter from January to August in 1967. The dip of $0.11-0.12$ points from age one to age two is probably overstated. In the four preceding years (1965-1968) the cross-section second year dip averaged only 0.027. But these higher initial depreciation rates in Britain remain out of line with our argument, and may indeed display a local 'lemon' behaviour. If that is indeed the case, then the most likely explanation is that new list prices were discounted heavily in new-car purchase transactions. This is plausible given the large share of fleet sales in Britain. Genuine adverse selection could also arise if British new-car quality was exceptionally poor, for which there is indeed ample evidence (Whisler, 1999, pp. 327-49, 358-9). By year two, a 'lemon' would be fixed, or could not be so easily disguised, and depreciation levels could then fall substantially to their long-run equilibrium. British depreciation rates were usually about six percentage points less than American ones during the 1960s. Due to higher taxation, British cars were made at even lower cost than price differences suggest, and less efficiently as well. Why they held their values better than American cars is considered later.

On the whole, then, the six sampling frames confirm that depreciation rates usually increased in time, with lower depreciation rates in Britain (except for year one). But there were exceptions: apparent first-year 'lemon' effects were evident

16 Also observed by Purohit (1992, p. 164) for 1975-1985 cohorts in the USA. 
in the USA Ford cross-section of the late 1960s, and were pervasive in Britain, also in the late 1960s. In general, therefore, higher initial depreciation rates were only seen in a minority of cases. But there is room to doubt the 'lemon' interpretation even in these cases: in both these instances, higher initial depreciation is also replicated in retail-to-retail depreciation, which should largely be immune to adverse selection. This makes it more likely that what we observe is a cohort or period effect, and weakens the case for regarding it as evidence for 'lemons'. At the most, a typical 'lemon' pattern (exceptional depreciation in year one) would sometimes emerge under local conditions, but was not the common pattern. 


\section{Dealer Markups}

An alternative measure of Akerlof's initial depreciation is the size of dealer markups. Dealer markups are defined here as the difference between the retail price and the wholesale price of a particular model in a particular year, expressed as a percentage of the retail price. This is different from depreciation, which compared current car prices to those in the previous year. Apart from almost-new cars fresh out of the showroom (a special case for which no used-car-wholesaleprice is available), this is a better measure of Akerlof depreciation - it captures the instantaneous loss of value that occurs when a car changes hands from dealer to buyer. Table 2 shows that that markups increased with age as a percentage of selling price. Markups were also higher and rose faster for American than for European cars.

TABLE 2

MEAN USED-CAR MARKUPS BY AGE (PERCENT OF RETAIL PRICE)

\begin{tabular}{lccclcc}
\hline Make Age & 1 & 2 & \multicolumn{1}{c}{3} & \multicolumn{1}{c}{4} & 5 & 6 \\
\hline Buick 1957 cross-section & 16.2 & $18.3^{* *}$ & $20.8^{* *}$ & $27.4^{* *}$ & 30.00 & \\
Buick 1957 panel & 16.9 & $20.4^{* *}$ & $23.9^{* *}$ & $29.4^{* *}$ & $32.3^{* *}$ & \\
Ford 1957 cross-section & 18.9 & $22.0^{* *}$ & $28.6^{* *}$ & $29.7^{*}$ & & \\
Ford 1957 panel & 19.1 & $22.3^{* *}$ & $23.5^{* *}$ & $31.5^{* *}$ & $30.5^{*}$ & \\
Buick 1969 cross-section & 15.5 & $18.0^{* *}$ & $21.2^{* *}$ & $25.8^{* *}$ & & \\
Buick 1968 panel & 15.5 & $18.9^{* *}$ & $20.5^{* *}$ & $23.2^{* *}$ & $30.6^{* *}$ & \\
Ford 1969 cross-section & 16.8 & $19.3^{* *}$ & $25.9^{* *}$ & $32.0^{* *}$ & & \\
Ford 1968 panel & 16.8 & $21.9^{* *}$ & $24.7^{* *}$ & $30.6^{* *}$ & $37.4^{* *}$ & \\
USA(non weighted) & $\mathbf{1 6 . 9}$ & $\mathbf{2 0 . 1}$ & $\mathbf{2 3 . 6}$ & $\mathbf{2 8 . 7}$ & $\mathbf{3 2 . 2}$ & \\
UK 1969 cross-section & 15.1 & $16.1 *$ & 18.1 & 20.1 & $22.5^{* *}$ & $25.0 *$ \\
& & & & & & $*$ \\
UK 1968 panel & 15.1 & $15.7^{*}$ & 17.8 & $20.9 * *$ & $25.3 * *$ & \\
UK (non-weighted) & $\mathbf{1 5 . 1}$ & $\mathbf{1 5 . 9}$ & $\mathbf{1 7 . 9 5}$ & $\mathbf{2 0 . 5}$ & $\mathbf{2 3 . 9}$ & \\
Volkswagen 1950s & 22.4 & 24.4 & 24.2 & 25.6 & 28.7 & 33.6 \\
Volkswagen 1960s & 20.1 & 23.4 & 27.1 & 30.3 & 35.8 & 44.8 \\
\hline
\end{tabular}

Sources: see text. $* *$ significantly different from year-younger car at

$1 \%$ level. *significantly different from year-younger car at $5 \%$ level.

Our hypothesis is that the greater the uncertainty about the condition of wholesale cars, the higher the dealer markup as a percentage of price. This is an extension to older cars of Akerlof's insight, that uncertainty about quality affected selling margins. But although markups increased with age as a percentage of selling price, in absolute terms they remained roughly constant even for cars of different 
initial prices and quality. This suggests that absolute markups were capped by competition, and held up by inelastic selling costs.

This is tested in the regressions reported in table 3. Two controls are added: intrinsic differences in initial quality are controlled for by a variable consisting of the price when new., and there is a control for the make of car.

Our model is

$$
\text { (1) } \text { MARKUPPC }_{i t}=\alpha+\beta_{1} \mathrm{NEW}_{i t}+\beta_{2} \mathrm{FORD}_{i}+\beta_{3-6} \mathrm{AGE}_{i}+\varepsilon_{i t}
$$

where MARKUPPC $=\left(\right.$ Price $_{\text {retail }}-$ Price $\left._{\text {wholesale }}\right) /$ Price $_{\text {retail }}$ for model $i$ at time $t$. NEW is the retail price of the car model when new. This variable is intended to capture the quality ranking of the model when new and to test for the persistence of a quality ranking premium in older cars. FORD is the make indicator variable (the reference variable is Buick or Morris for the United States and Britain respectively), and AGE is an age-of-car indicator variable. It might be desirable to test the hypothesis that depreciation affects markups, but depreciation is collinear with AGE. A separate variable for the absolute dollar value of markups was also estimated, but proved to be small, collinear, and only marginally significant, and has been dropped. The log form provides a slightly better fit, as well as a direct measure of elasticity. Cross-sections are estimated by independently pooled OLS. Panels are estimated with GLS random effects regressions. ${ }^{17}$ Observations are not weighted by sales. Weighting is neither practical nor desirable. The data (for an American sub-region and for particular sub-periods) would be impossible to obtain. Weighting would be detrimental, since the objective is not in this case to estimate the overall economic impact of depreciation, but to obtain the largest number of separate observations. Any weighting would dilute this information.

The regressions in table 3 indicate that markups increase with age. That is consistent with expectations. The effect of new car prices, however, is unexpected. The coefficient is large and of the 'wrong' sign. New-car prices have a remarkably stable negative elasticity in markups of about -0.52 for three out of four samples controlling for age and make, and -0.66 for the fourth. In other words, the more expensive the car when new, the lower the used-car markup. Expensive used-car models delivered a smaller percentage margin for dealers

17 Cross-section time-series panel estimates corrected for autocorrelation and with robuststandard-errors have also been tested, and make only very small and insignificant differences to coefficients and errors. 


\section{TABLE 3}

\section{RETAIL CAR MARKUPS}

(dependent variable: $(\log )$ percent markup)

\begin{tabular}{|c|c|c|c|c|c|c|}
\hline LOG OF & (1) & (2) & (3) & (4) & (5) & (6) \\
\hline PERCENT & USA & USA & USA & USA & UK & UK \\
\hline MARKUP & Cross-sec & Cross-sec & Panel & Panel & Cross-sec & Panel \\
\hline & $1957^{1}$ & $1969^{1}$ & $1957^{2}$ & $1968^{2}$ & $1968^{1}$ & $1968^{2}$ \\
\hline \multirow[t]{2}{*}{ LOGNEW } & -0.659 & -0.527 & -0.518 & -0.520 & -0.018 & 0.115 \\
\hline & $(0.062)^{* *}$ & $(0.045)^{* *}$ & $(0.045)^{* *}$ & $(0.055)^{* *}$ & $(0.032)$ & $(0.065)$ \\
\hline \multirow[t]{2}{*}{ FORD } & -0.074 & 0.072 & \multirow{2}{*}{$\begin{array}{c}-0.112 \\
(0.019)^{* *}\end{array}$} & 0.083 & -0.069 & -0.058 \\
\hline & $(0.027)^{* *}$ & $(0.012)^{* *}$ & & $(0.018)^{* *}$ & $(0.013)^{* *}$ & $(0.024)^{*}$ \\
\hline \multirow[t]{2}{*}{ AGE2 } & 0.136 & 0.160 & \multirow{2}{*}{$\begin{array}{c}0.166 \\
(0.010)^{* *}\end{array}$} & 0.237 & 0.067 & 0.095 \\
\hline & $(0.016) * *$ & $(0.014)^{* *}$ & & $(0.009)^{* *}$ & $(0.012)^{* *}$ & $(0.016)^{* *}$ \\
\hline \multirow[t]{2}{*}{ AGE3 } & 0.355 & 0.366 & \multirow{2}{*}{$\begin{array}{c}0.253 \\
(0.010)^{* *}\end{array}$} & 0.344 & 0.183 & 0.160 \\
\hline & $(0.019)^{* *}$ & $(0.013)^{* *}$ & & $(0.009)^{* *}$ & $(0.013)^{* *}$ & $(0.016)^{* *}$ \\
\hline \multirow[t]{2}{*}{ AGE4 } & 0.480 & 0.533 & \multirow{2}{*}{$\begin{array}{c}0.522 \\
(0.010)^{* *}\end{array}$} & 0.531 & 0.289 & 0.324 \\
\hline & $(0.029) * *$ & $(0.016)^{* *}$ & & $(0.009)^{* *}$ & $(0.015)^{* *}$ & $(0.016)^{* *}$ \\
\hline \multirow[t]{2}{*}{ Constant } & 8.106 & 6.837 & \multirow{2}{*}{$\begin{array}{c}7.065 \\
(0.365)^{* *}\end{array}$} & 6.792 & 2.867 & 1.982 \\
\hline & $(0.497)^{* *}$ & $(0.349)^{* *}$ & & $(0.432)^{* *}$ & $(0.215)^{* *}$ & $(0.426)^{* *}$ \\
\hline $\mathrm{N}$ & 123 & 366 & 216 & 416 & 59 & 69 \\
\hline $\mathrm{N}$ models & & & 54 & 104 & & 18 \\
\hline R-squared & 0.88 & 0.83 & $0.92^{3}$ & $0.86^{3}$ & 0.92 & $0.81^{3}$ \\
\hline \multirow{2}{*}{\multicolumn{4}{|c|}{$\begin{array}{l}{ }^{1} \text { Robust standard errors in parentheses } \\
{ }^{2} \text { Standard Errors in parenthesis }\end{array}$}} & & d OLS & \\
\hline & & & & rando1 & & \\
\hline$*_{\operatorname{sio}}$ & & 1 & & nificar & ercen & \\
\hline
\end{tabular}

in comparison with cheaper cars (White, 1971, p. 106). This suggests that the main determinant of markups were the fixed selling costs. The initial novelty premium could not be maintained as cars aged.

Selling costs, in dollar terms, remained approximately constant at all ages. This is captured by the variance of absolute dollar markups within each sample. The mean coefficient of variance for all four American samples, over all ages was only 0.17 (16 observations, unweighted; min. 0.15 , max. 0.21). ${ }^{18}$ As we have seen, about three-quarters of new dealership costs were fixed, i.e. spent on staff and premises (n. 6 above). In a competitive market without cross-subsidy, inelastic fixed costs caused percentage markups to be low on newer cars, and high on older ones. Dealers could and often did cross-subsidise, e.g. overpricing

182 makes x ( 4 cross-sections +4 panels). 
trade-offs in order to sell new cars, but the handbook car prices that we use ignore such ruses and rest on the bedrock of realisable market value.

Quality uncertainty and the fixed costs of selling, jointly placed a limit on the ability of dealers to sell older cars. Table 4 is derived from a Federal Trade Commission nationally-representative survey of car buyers in 1979-80 (Lacko, 1986; Genesove, 1993). It shows the percentage of cars of every age sold in three types of transactions: by new car dealers, by exclusively used car dealers, and by private traders. In this sample, used cars less than one year old were traded, though in smaller numbers than older ones. Four-fifths of cars under oneyear old (25) were sold by new car dealers, who alone could provide credible warranties. But one-fifth (7 cars) were sold privately. Dealers facilitated exchange, but a few private individuals also found the confidence to trade. It was the high transaction cost (some 30 to percent of a new car's price) that must have largely discouraged trade in almost-new cars.

TABLE 4

MARKET SHARES OF USED CARS BY AGE, USA, DEC. 1979

\begin{tabular}{ccccc}
\hline Intermediary & $\mathrm{N}$ cars & $\%$ share & $\%$ age $>5$ & $\mathrm{~N} \mathrm{age}<1$ \\
\hline New car dealers & 335 & 33.2 & 30 & 25 \\
Used car dealers & 149 & 14.8 & 57 & 2 \\
Private sales & 524 & 52.0 & 76 & 7 \\
Total & 1008 & 100 & & 32 \\
\hline
\end{tabular}

Source: Genesove (1993, table 1, p. 651)

Five-year-old cars had markups in excess of 30 per cent of shrinking retail prices (Table 2 above). As these cars depreciated, the markups required to recondition, sell, and guarantee the cars increased as a proportion of their price. This reduced competitiveness with private sellers, who had few of these costs. Consequently, new car dealers largely withdrew from this market, and customers took on the risk themselves. Self-insurance was a reasonable choice for such buyers since older cars (more than five years) were cheap, having lost some fourfifths of their initial values. Some business was taken over by dealers specialising in used cars (whose facilities and warranties would be more limited), but for older cars overall, the transaction costs were too high for intermediaries, and the large bulk of such cars were bought and sold privately (table 4). It was only at this stage that the 'lemon' risk was finally shifted from seller to buyer. Interestingly, in some other studies, it is only in the oldest cars (more than ten and seven 
years old respectively) that any adverse selection effects could be detected (Bond, 1982; Lacko, 1986).

Table 4 shows that the almost-new market was not thin. There was manifestly an incentive to ignore any risk of adverse selection and absorb high transaction costs in order to dispose of such cars, where that was necessary. There is other evidence as well: in the 1950s, 5-6 percent of new cars were re-sold in less than a year, and another 10-11 percent after one to two years (Crowell-Collier, 1955, p. 18; Look, 1960 , p. 26). In the 1960 s, most rental cars were sold after a year (White, 1971, p. 169). In a 1979-80 survey, 7.5 percent of used cars sold by new-car dealers were less than one year old (Genesove, 1993, table 1, p. 651, col. 1). Of a very large sample of business-lease cars in the $1980 \mathrm{~s}$, one third were re-sold within the first year (calculated from Wykoff, 1989, table 6.2, p. 270-1). Trade was manifestly not disabled. Any problem of adverse selection appears to have been solved by the market through the use of dealer guarantees.

British cars differed from American ones: The new car price ranking (table 3, variable (LOG)NEW, cols. 5, 6) persisted for older car markups, i.e. the coefficient was not significantly different from zero. And the age markup increment was much lower in comparison with American cars. In other words, British cars depreciated much less than American ones, and British dealers earned lower markups. 


\section{The Influence of Styling}

Car-price manuals do not provide usable evidence on the hedonic attributes of particular cars, either mechanical or styling ones. Some evidence of a styling effect can nevertheless be detected in a comparison of American, British, and USA Volkswagen depreciation rates. American and European manufacturers followed different styling strategies. During the 1950s, the dominant American manufacturers were absorbed in a frenzied styling race, with annual face-lifts which relegated older models to stylistic obsolescence (Fisher et al., 1962; Offer, 1998). This styling frenzy slowed down somewhat during the 1960s (Pashigian et al, 1995, p. 291-2). In Britain, in contrast, the styling cycle was much slower. Ford renewed their models about every four years, while Morris kept models in production for at least a decade, and sometimes much longer.

In Britain, the novelty signal was a letter on the licence plate, updated once a year. It was uniform and costless. In the United States, novelty was signalled expensively for each model by means of annual styling facelifts. Aggressive styling innovation generated higher depreciation rate variance, and depreciated older cars more rapidly, quite apart from any difference in mechanical quality. ${ }^{19}$

Depreciation rates (Figure 2 above) highlight the much more dynamic and competitive styling/innovation regime in the United States, compared with Britain. Apart from year one, British depreciation rates were about one-fifth lower than American ones, despite poor British mechanical quality. Model attrition was much faster in the United States. In the cross-sections, earlier models were discontinued rapidly. For example, In table A1 (cross-sections) the number of observations in 1957 starts with 120 in age one, and peters out down to 39 by age four. In the UK cross-section, by comparison, only three depreciation observations were lost (out of 42) between ages two and six.

Volkswagen USA followed a 'Model T' styling strategy (after Henry Ford's unchanging first mass-production car), and promised to improve mechanical quality, without altering the basic design. ${ }^{20}$ Volkswagen had economies of scale in its European markets, and lower labour costs. It sold a small car more cheaply than any American producer, and made a virtue of a single, reliable, economical, and unchanging design. Volkswagen USA sales grew 35 percent a year between

\footnotetext{
19 Purohit (1992) shows that used car prices could respond positively as well as negatively to new car styling changes.

${ }^{20}$ Volkswagen USA ads: http://www.ciadvertising.org/studies/student/99_spring/interactive/ joohwan/bernbach/images/vwad15.gif. Accessed 25 March 2003. Copies in possession of the author.
} 
1955 and 1961, up to 177,000 annual unit sales. Customers were credibly shielded from fashion obsolescence, a point stressed in company advertising. Volkswagen retail-retail depreciation was exceptionally low. Between 1956 and 1958, one-year-old sedans actually sold for more than the list price of new ones (calculated from $N A D A$ ).

Indigenous British manufacturers also followed a 'Model T' policy. The Morris Minor (introduced in 1949), was produced unchanged for 23 years, the Morris/Austin Mini (1959) only went out of production in 1991, and the popular the Morris/Austin 1100 ran unchanged for ten years (Foreman-Peck et al., 1995, p. 129, 140-2). The vintage indicated on the licence plate provided a cheap novelty signal. Table 5 shows that British cars and Volkswagen in the United States depreciated much less than comparable American cars. After five years, a British car (or Volkswagen in the United States) was worth almost 50 percent more than an American one of the same age, as a proportion of the original price.

TABLE 5

Wholesale Prices as Percentage of NeW Prices, AMERICAN AND EUROPEAN MAKES

\begin{tabular}{lllllllll}
\hline & Ford & Buick & Ford & Buick & VW & VW & Ford & Morris \\
& USA & USA & USA & USA & USA & USA & UK & UK \\
\hline Age new & 1957 & 1957 & 1968 & 1968 & 1957 & 1968 & 1968 & 1968 \\
New price & 100 & 100 & 100 & 100 & 100 & 100 & 100 & 100 \\
age1 & 66 & 63 & 60 & 67 & 81 & 73 & 67 & 66 \\
age2 & 51 & 47 & 43 & 50 & 69 & 62 & 62 & 61 \\
age3 & 40 & 35 & 36 & 43 & 57 & 49 & 51 & 52 \\
age4 & 20 & 20 & 24 & 34 & 35 & 40 & 41 & 42 \\
age5 & 19 & & 17 & 23 & 31 & 29 & 31 & 32 \\
\hline
\end{tabular}

Mean of models in panels. Deflated prices

Were British cars more mechanically durable? That is unlikely — they failed in the American market while Volkswagen succeeded. They were built at much lower cost. They had poor quality reputations (Whisler, 1998, p. 327-49, 358-9). If roads in New England were heavily salted, British roads were salted as well. The low variance in Glass's Guide might suggest that the prices reported might have been derived from a formula, rather than reported empirically, but the strong 
Ford cohort effect in age three (table A2) suggests otherwise, and so does the variance in $2^{\text {nd }}$ year UK depreciation over several years.

For both the UK models and for Volkswagen in the USA, there was less uncertainty about fashion durability. In the United States, with its styling race, makers could not credibly commit not to innovate (Coase, 1972; Purohit, 1992). British producers (and Volkswagen USA) could do so. That was reflected in lower depreciation, and lower markups. Although styling strategies was unlikely to be the only source of depreciation level difference between the two markets, the evidence remains suggestive. During the build-up of mass-market popular motorization, cheap individual transport was sufficiently compelling for new-car buyers without the additional bait of styling novelty. In developing markets, the 'Model T' styling strategy of Volkswagen, of Morris and Ford in Britain, of Renault and Citroen in France, of Fiat in Italy had the attraction, for new-car buyers, of avoiding fashion uncertainty and obsolescence, and thus of reducing depreciation and transaction costs. Production of VW 'beetles' ended in Europe in 1978, but continued to be viable in a developing country, Mexico, for another 25 years. In the 1960s Britain still had the relatively low depreciation of a stable styling regime, and it never fully embraced the pace of styling change observed in the United States during the 1950s and 1960s (Sherman and Hoffer, 1971; Hoffer and Reilly, 1984; Millner and Hoffer, 1993; Offer, 1998). The 'folk wisdom' which explained initial price declines by the exhaustion of novelty, appears to have contained a kernel of truth. 


\section{Conclusion}

Akerlof's model of almost-new car prices is empirically indeterminate. It is consistent with three different outcomes: (i) no trading, (ii) trading with depressed prices, or (iii) trading with dealer warranties. He did not consider another possibility, namely that new-car 'lemons' were rare, and were not sufficiently frequent to impinge on car trading. Factory-fresh used cars were a special case, hardly ever sold, but not necessarily for adverse-selection reasons. For cars during their first year, dealer warranties appear to have enabled trading. The stylised fact of exceptional initial depreciation, accepted by many previous writers, is explained by their overlooking the shift from a retail to a wholesale depreciation curve when a vehicle was sold. The actual pattern found is that (i) trading existed, normally mediated by dealers; (ii) initial depreciation was no higher, and was usually lower, than depreciation of older cars. Dealer services were mostly genuine transaction costs, reflecting the real cost of doing business in a competitive market. As cars aged, fixed costs increased as a percentage of value, until fullservice dealers could no longer afford to trade in competition with private sellers and limited-service dealers. Earlier studies have found that adverse selection was only weakly present (if at all) in older cars. It is now shown that adverse selection left no enduring mark on the price of cars at the end of their first year either. In general, the evidence for the widespread effect of 'lemons' is weak. It suggests that 'lemons' was not a pervasive hazard, although they might appear in particular local circumstances. As an empirical matter, the used car market may not have been the best example to use in demonstrating the effect of 'lemons'. Popular intuitions about reality can be wrong.

Styling appears to have affected price independently. American makes signalled novelty by means of styling changes. British makes (and Volkswagen USA) sent a reassuring no-novelty message. American depreciation and markups were higher, with a greater quality variance giving rise to greater risks. In mature American markets, consumers paid for styling with higher depreciation. In the developing British one, they avoided much of this cost. 


\section{References}

Akerlof, G.-A. (1970) The Market for 'Lemons': Quality Uncertainty and the Market Mechanism, Quarterly Journal of Economics, 84, 488-500.

Automobile Manufacturers' Association (1961) Automobile Facts and Figures, Automobile Manufacturers' Association, Detroit.

Bond, E. W. (1982) A Direct Test of the 'Lemons' Model: The Market for Used Pickup Trucks, American Economic Review, 72, 836-40.

Bond, E. W. (1984) Test of the Lemons Model: Reply, American Economic Review, 74, 801-4.

Coase, R. (1972) Durability and Monopoly, Journal of Law and Economics, 15, $143-9$.

Crowell-Collier (1955) Automotive Survey, 19.

Emons, Winand and Sheldon, George (2002) The Market for Used Cars: A New Test for the Lemons Model, Centre for Economic Policy Research, discussion paper no. 3360, London.

Fisher, F. M., Griliches, Z., and Kaysen, C.(1962) The Costs of Automobile Model Changes since 1949, The Journal of Political Economy, 52, 433-51

Ford Motor Company (1957) Product Planning Committee, Ford Industrial Archives, AR-94-200777-6, Detroit.

Ford Motor Company (1957) Product Planning Office, Economy Car Report, Ford Industrial Archives, AR-94-200777-5, Detroit.

Foreman-Peck, J., Bowden, S. and McKinlay, A. (1995) The British Motor Industry, Manchester University Press, Manchester.

Genesove, D. (1993) Adverse Selection in the Wholesale Used Car Market, The Journal of Political Economy, 101, 644-65.

Glass's Guide Service Limited (1968-1973) Glass's Guide to Used Car Values, Glass's Guide Service Limited, Weybridge.

Harford, Tim (2005) The Undercover Economist: Exposing Why the Rich Are Rich, the Poor Are Poor - and Why You Can Never Buy a Decent Used Car! Oxford University Press, New York.

Harless, D. W. and Hoffer, G. E. (2002) Do Women Pay More for New Vehicles? Evidence from Transaction Price Data, American Economic Review, 92, $270-9$. 
Hendel, I. and Lizzeri, A. (1999) Adverse Selection in Durable Goods Markets, American Economic Review, 89, 1097-115.

Hoffer, G. E. and Reilly, R. J. (1984) Automobile Styling as a Shift Variable: An Investigation by Firm and by Industry, Applied Economics, 16, 291-7.

Kim, J. C. (1985) The Market for "Lemons" Reconsidered: A Model of the Used Car Market with Asymmetric Information, American Economic Review, 75, 836-43.

Lacko, J. (1986) Product Quality and Information in the Used Car Market, Federal Trade Commission, Bureau of Economics, Washington D.C.

Laibson, D.I., Rebetto, A., Tobacman, J., and Weinberg, S. (2003) The Hyperbolic Consumption Model: Calibration, Simulation and Empirical Evaluation, in G. Leowenstein, D. Read and R.F. Baumeister (eds.), Time and Decision: Economic and Psychological Perspectives on Intertemporal Choice, Russell Sage Foundation, New York, 517-43.

Look (1960) National Automobile and Tire Survey, 24, New York.

Millner, E. L. and Hoffer, G. E. (1993) A Re-Examination of the Impact of Automotive Styling on Demand, Applied Economics, 25, 101-10.

National Automobile Dealers' Association (1957-1973) Official Used Car Guide, Eastern Edition. National Automobile Dealers' Association, Washington, D.C.

Northwood Institute (1967) Merchandising Cars and Trucks, Midland, MI.

Offer, A. (1998) The American Automobile Frenzy of the 1950s, in K. Bruland and P. K. O'Brien (eds.) From Family Firms to Corporate Capitalism : Essays in Business and Industrial History in Honour of Peter Mathias, Clarendon Press, Oxford.

Parker Mead Ltd (1996) Parker's Car Price Guide, December, London.

Pashigian, B. P. (1961) The Distribution of Automobiles, an Economic Analysis of the Franchise System, Prentice-Hall, Englewood Cliffs, NJ.

Pashigian, B. P., Bowen, B. and Gould, E. (1995) Fashion, Styling, and the Within-Season Decline in Automobile Prices, Journal of Law and Economics, 38, 281-309.

Porter, R. H. and Sattler, P. (1999) Patterns of Trade in the Market for Used Durables: Theory and Evidence, NBER Discussion Paper No. 7149, Cambridge MA. 
Purohit, D. (1992) Exploring the Relationship between the Markets for New and Used Durable Goods: The Case of Automobiles, Marketing Science, 11, 15467.

Rachlin, H. and Raineri, A. (1992), Irrationality, Impulsiveness, and Selfishness as Discount Reversal Effects, in G. Leowenstein, D. Read and R.F. Baumeister (eds.), Time and Decision: Economic and Psychological Perspectives on Intertemporal Choice, Russell Sage Foundation, New York.

Sherman, R. and Hoffer, G. (1971) Does Automobile Style Change Payoff?, Applied Economics, 3, 153-65.

Smith, R. P. (1975) Consumer Demand for Cars in the USA, Cambridge University Press, Cambridge.

Sugden, R. (2000) Credible Worlds: The Status of Theoretical Models in Economics, Journal of Economic Methodology, 7, 1-31.

United States Council of Economic Advisers (1991) Economic Report of the President, United States Council of Economic Advisers, Washington, D.C.

Ward's Reports Inc. (1938ff.) Ward's Automotive Yearbook, Ward's Reports Inc., Detroit.

Whisler, T. R. (1999) The British Motor Industry, 1945-1994 : A Case Study in Industrial Decline, Oxford University Press, Oxford.

White, L. J. (1971) The Automobile Industry since 1945, Harvard University Press, Cambridge, MA.

Wykoff, F. C. (1973) A User Cost Approach to New Automobile Purchases, Review of Economic Studies, 40, 377-90.

Wykoff, F. C. (1989), Economic Depreciation and the User Cost of BusinessLeased Automobiles, in D. W. Jorgenson and R. Landau (eds.) Technology and Capital Formation, MIT Press, Cambridge, MA 


\section{Appendix A. Depreciation Rates}

Depreciation rates are generated using the following procedure:

(1) DEPR $_{i t}=\beta_{1}$ RWBUICK $_{i t}+\beta_{2}$ RRBUICK $_{i t}+\beta_{3}$ WWBUICK $_{i t}$ $+\beta_{4}$ RWFORD $_{i t}+\beta_{5}$ RRFORD $_{i t}+\beta_{6}$ WWFORD $_{i t}+\varepsilon_{i t}$

The dependent variable DEPR is depreciation rate of model $i$ at age $t$.

$$
\text { DEPR }_{i t}=\left(\text { Price }_{i t-1}-\text { Price }_{i t}\right) / \text { Price }_{i t-1}
$$

DEPR normalizes market prices, allowing comparisons over time. Independent variables are all interactive indicator variables. RW stands for retail to wholesale depreciation, RR stands for retail to retail price depreciation, and WW is wholesale-to-wholesale price depreciation. BUICK and FORD (MORRIS in the UK) are make dummies. The method is independently pooled OLS cross-sections, with a separate a separate regression for each age, and the constant forced to zero. Mean depreciation rates can thus be read directly from the coefficients. Errors are reported as confidence intervals, which allows for pairwise comparison of coefficients within and across regressions. 
TABLE A1

USA AND BRITISH AUTOMOBILE DEPRECIATION RATES, CROSS-SECTIONS (a) USA 1957 Cross-section

\begin{tabular}{lcccc}
\hline Age & $\mathbf{1}$ & $\mathbf{2}$ & $\mathbf{3}$ & $\mathbf{4}$ \\
RWBUICK & DEPR & DEPR & DEPR & DEPR \\
& 0.291 & 0.354 & 0.392 & 0.487 \\
RRBUICK & $0.269-0.314)$ & $(0.340-0.368)$ & $(0.382-0.401)$ & $(0.476-0.498)$ \\
& $(0.124-0.184)$ & $(0.195-0.223)$ & $(0.222-0.242)$ & $(0.282-0.305)$ \\
WWBUICK & 0.195 & 0.227 & 0.258 & 0.352 \\
& $(0.169-0.220)$ & $(0.210-0.244)$ & $(0.251-0.266)$ & $(0.342-0.363)$ \\
RWFORD & 0.295 & 0.383 & 0.425 & 0.440 \\
& $(0.268-0.321)$ & $(0.361-0.404)$ & $(0.395-0.455)$ & $(0.424-0.457)$ \\
RRFORD & 0.130 & 0.241 & 0.221 & 0.195 \\
& $(0.105-0.154)$ & $(0.216-0.266)$ & $(0.208-0.235)$ & $(0.179-0.212)$ \\
WWFORD & 0.199 & 0.237 & 0.278 & 0.200 \\
& $(0.168-0.229)$ & $(0.212-0.263)$ & $(0.262-0.295)$ & $(0.183-0.218)$ \\
Observations & 120 & 114 & 84 & 39 \\
R-squared & 0.930 & 0.971 & 0.987 & 0.997 \\
\hline
\end{tabular}

(b) USA 1969 Cross-section

\begin{tabular}{lcccc}
\hline Age & $\mathbf{1}$ & $\mathbf{2}$ & $\mathbf{3}$ & $\mathbf{4}$ \\
\hline & DEPR & DEPR & DEPR & DEPR \\
RWBUICK & 0.316 & 0.343 & 0.384 & 0.409 \\
& $(0.308-0.323)$ & $(0.330-0.357)$ & $(0.372-0.396)$ & $(0.385-0.432)$ \\
RRBUICK & 0.190 & 0.200 & 0.217 & 0.204 \\
& & $(0.190-0.210)$ & $(0.206-0.229)$ & $(0.187-0.221)$ \\
WWBUICK & & 0.223 & 0.248 & 0.249 \\
& & $(0.210-0.237)$ & $(0.235-0.261)$ & $(0.226-0.273)$ \\
RWFORD & 0.393 & 0.351 & 0.437 & 0.460 \\
& $(0.386-0.400)$ & $(0.337-0.365)$ & $(0.428-0.446)$ & $(0.445-0.476)$ \\
RRFORD & 0.269 & 0.194 & 0.237 & 0.202 \\
& $(0.261-0.276)$ & $(0.182-0.206)$ & $(0.231-0.244)$ & $(0.193-0.212)$ \\
WWFORD & & 0.218 & 0.295 & 0.268 \\
& & $(0.203-0.232)$ & $(0.287-0.303)$ & $(0.254-0.283)$ \\
Observations & 202 & 288 & 240 & 213 \\
R-squared & 0.993 & 0.965 & 0.991 & 0.977 \\
\hline
\end{tabular}


(c) UK 1969 Cross-section

\begin{tabular}{lllllll}
\hline Age & $\mathbf{1}$ & $\mathbf{2}$ & $\mathbf{3}$ & $\mathbf{4}$ & $\mathbf{5}$ & $\mathbf{6}$ \\
\hline \multirow{2}{*}{ RWMORRIS } & 0.368 & 0.260 & 0.305 & 0.317 & 0.345 & 0.368 \\
& $(0.346-$ & $(0.252-$ & $(0.298-$ & $(0.306-$ & $(0.334-$ & $(0.356-$ \\
& $0.391)$ & $0.268)$ & $0.313)$ & $0.328)$ & $0.355)$ & $0.381)$ \\
RRMORRIS & 0.252 & 0.111 & 0.144 & 0.134 & 0.142 & 0.148 \\
& $(0.227-$ & $(0.103-$ & $(0.132-$ & $(0.129-$ & $(0.134-$ & $(0.110-$ \\
WWMORRIS & $0.277)$ & $0.120)$ & $0.156)$ & $0.140)$ & $0.150)$ & $0.186)$ \\
& & 0.123 & 0.166 & 0.156 & 0.170 & 0.173 \\
RWFORD & 0.349 & 0.238 & 0.361 & 0.303 & 0.331 & 0.343 \\
& $(0.338-$ & $(0.230-$ & $(0.346-$ & $(0.295-$ & $(0.323-$ & $(0.330-$ \\
& $0.361)$ & $0.246)$ & $0.376)$ & $0.311)$ & $0.339)$ & $0.356)$ \\
RRFORD & 0.236 & 0.097 & 0.228 & 0.137 & 0.147 & 0.131 \\
& $(0.225-$ & $(0.089-$ & $(0.210-$ & $(0.130-$ & $(0.138-$ & $(0.120-$ \\
& $0.247)$ & $0.105)$ & $0.245)$ & $0.145)$ & $0.157)$ & $0.142)$ \\
Observations & 28 & $0.134)$ & $0.176)$ & $0.164)$ & $0.178)$ & $0.183)$ \\
WWFuared & 0.995 & 0.997 & 0.996 & 0.998 & 0.998 & 0.992 \\
\hline
\end{tabular}

Robust 95 percent confidence intervals. New wholesale prices imputed at 88 percent of list in 1957. No imputation in 1969.

Sources: See text. 


\section{TABLE A2 \\ USA AND BRITISH AUTOMOBILE \\ DEPRECIATION RATES, PANEL DATA}

(a) USA 1957-1962 Panel

\begin{tabular}{|c|c|c|c|c|c|}
\hline Age & 1 & 2 & 3 & 4 & 5 \\
\hline & DEPR & DEPR & DEPR & DEPR & DEPR \\
\hline RWBUICK & $\begin{array}{l}0.365 \\
(0.345-0.385)\end{array}$ & $\begin{array}{l}0.378 \\
(0.371-0.386)\end{array}$ & $\begin{array}{l}0.417 \\
(0.409- \\
0.425)\end{array}$ & $\begin{array}{l}0.568 \\
(0.559- \\
0.578)\end{array}$ & $\begin{array}{l}0.600 \\
(0.588- \\
0.613)\end{array}$ \\
\hline RRBUICK & $\begin{array}{l}0.235 \\
(0.207-0.262)\end{array}$ & $\begin{array}{l}0.219 \\
(0.214-0.225)\end{array}$ & $\begin{array}{l}0.235 \\
(0.230- \\
0.239)\end{array}$ & $\begin{array}{l}0.389 \\
(0.378- \\
0.400)\end{array}$ & $\begin{array}{l}0.410 \\
(0.391- \\
0.429)\end{array}$ \\
\hline WWBUICK & $\begin{array}{l}0.278 \\
(0.256-0.301)\end{array}$ & $\begin{array}{l}0.252 \\
(0.246-0.258)\end{array}$ & $\begin{array}{l}0.268 \\
(0.261- \\
0.274)\end{array}$ & $\begin{array}{l}0.434 \\
(0.425- \\
0.442)\end{array}$ & $\begin{array}{l}0.433 \\
(0.418- \\
0.449)\end{array}$ \\
\hline RWFORD & $\begin{array}{l}0.338 \\
(0.326-0.350)\end{array}$ & $\begin{array}{l}0.376 \\
(0.367-0.386)\end{array}$ & $\begin{array}{l}0.401 \\
(0.393- \\
0.408)\end{array}$ & $\begin{array}{l}0.614 \\
(0.606- \\
0.621)\end{array}$ & $\begin{array}{l}0.339 \\
(0.313- \\
0.366)\end{array}$ \\
\hline RRFORD & $\begin{array}{l}0.181 \\
(0.169-0.192)\end{array}$ & $\begin{array}{l}0.195 \\
(0.189-0.201)\end{array}$ & $\begin{array}{l}0.215 \\
(0.210- \\
0.219)\end{array}$ & $\begin{array}{l}0.433 \\
(0.424- \\
0.442)\end{array}$ & $\begin{array}{l}0.045 \\
(0.009- \\
0.081)^{*}\end{array}$ \\
\hline WWFORD & $\begin{array}{l}0.248 \\
(0.234-0.262)\end{array}$ & $\begin{array}{l}0.228 \\
(0.220-0.236)\end{array}$ & $\begin{array}{l}0.226 \\
(0.221- \\
0.231)\end{array}$ & $\begin{array}{l}0.494 \\
(0.486- \\
0.501)\end{array}$ & $\begin{array}{l}0.029 \\
(-0.010- \\
0.069)\end{array}$ \\
\hline Observations & 162 & 162 & 162 & 162 & 153 \\
\hline R-squared & 0.977 & 0.995 & 0.997 & 0.998 & 0.933 \\
\hline
\end{tabular}


(b) USA 1968-1973 Panel

\begin{tabular}{llllll}
\hline Age & $\mathbf{1}$ & $\mathbf{2}$ & $\mathbf{3}$ & $\mathbf{4}$ & $\mathbf{5}$ \\
\hline \multirow{2}{*}{ RWBUICK } & DEPR & DEPR & DEPR & DEPR & DEPR \\
& 0.331 & 0.373 & 0.291 & 0.379 & 0.468 \\
& $(0.324-$ & $(0.358-$ & $(0.280-$ & $(0.367-$ & $(0.449-$ \\
& $0.338)$ & $0.389)$ & $0.301)$ & $0.391)$ & $0.488)$ \\
RRBUICK & 0.208 & 0.228 & 0.107 & 0.191 & 0.235 \\
& $(0.201-$ & $(0.213-$ & $(0.095-$ & $(0.177-$ & $(0.213-$ \\
& $0.216)$ & $0.244)$ & $0.120)$ & $0.204)$ & $0.257)$ \\
WWBUICK & & 0.259 & 0.125 & 0.218 & 0.306 \\
& & $(0.242-$ & $(0.111-$ & $(0.202-$ & $(0.279-$ \\
& & $0.276)$ & $0.139)$ & $0.234)$ & $0.334)$ \\
RWFORD & 0.404 & 0.398 & 0.355 & 0.504 & 0.508 \\
& $(0.397-$ & $(0.384-$ & $(0.348-$ & $(0.494-$ & $(0.496-$ \\
& $0.410)$ & $0.411)$ & $0.363)$ & $0.515)$ & $0.519)$ \\
RRFORD & 0.283 & 0.228 & 0.142 & 0.283 & 0.211 \\
& $(0.276-$ & $(0.215-$ & $(0.133-$ & $(0.274-$ & $(0.202-$ \\
& $0.290)$ & $0.241)$ & $0.150)$ & $0.292)$ & $0.219)$ \\
WWFORD & & 0.275 & 0.172 & 0.341 & 0.288 \\
& & $(0.261-$ & $(0.162-$ & $(0.331-$ & $(0.277-$ \\
& & $0.289)$ & $0.182)$ & $0.351)$ & $0.299)$ \\
Observations & 210 & 312 & 312 & 312 & 312 \\
R-squared & 0.993 & 0.970 & 0.975 & 0.986 & 0.978 \\
\hline
\end{tabular}


(c) UK 1968-1973 Panel

\begin{tabular}{llllll}
\hline Age & $\mathbf{1}$ & $\mathbf{2}$ & $\mathbf{3}$ & $\mathbf{4}$ & $\mathbf{5}$ \\
\hline \multirow{2}{*}{ RWMORRIS } & DEPR & DEPR & DEPR & DEPR & DEPR \\
& $(0.342$ & 0.230 & 0.288 & 0.349 & 0.409 \\
& $0.356)$ & $(0.197-$ & $(0.264-$ & $(0.332-$ & $(0.381-$ \\
RRMORRIS & 0.221 & $0.262)$ & $0.313)$ & $0.366)$ & $0.436)$ \\
& $(0.205-$ & $(0.041-$ & 0.131 & 0.176 & 0.204 \\
& $0.238)$ & $0.101)$ & $0.161)$ & $(0.163-$ & $(0.170-$ \\
WWMORRIS & & 0.089 & 0.141 & 0.206 & $0.238)$ \\
& & $(0.051-$ & $(0.107-$ & $(0.194-$ & 0.249 \\
& & $0.127)$ & $0.175)$ & $0.217)$ & $0.285)$ \\
RWFORD & 0.331 & 0.211 & 0.284 & 0.344 & 0.386 \\
& $(0.316-$ & $(0.170-$ & $(0.257-$ & $(0.328-$ & $(0.370-$ \\
& $0.346)$ & $0.253)$ & $0.311)$ & $0.360)$ & $0.403)$ \\
RRFORD & 0.216 & 0.081 & 0.133 & 0.172 & 0.183 \\
& $(0.202-$ & $(0.050-$ & $(0.103-$ & $(0.157-$ & $(0.171-$ \\
& $0.230)$ & $0.113)$ & $0.163)$ & $0.187)$ & $0.195)$ \\
WWFORD & & 0.075 & 0.164 & 0.206 & 0.225 \\
& & $(0.024-$ & $(0.120-$ & $(0.190-$ & $(0.208-$ \\
& & $0.127)$ & $0.207)$ & $0.222)$ & $0.242)$ \\
Observations & 36 & 51 & 51 & 51 & 45 \\
R-squared & 0.995 & 0.886 & 0.956 & 0.994 & 0.989 \\
\hline
\end{tabular}

Robust 95 percent confidence intervals in parentheses. New wholesale prices imputed at 88 percent of list in 1957. No imputation in 1968.

Deflation, USA, 1956 prices, UK, $1967-8$ prices $\left(2 / 3 \mathrm{rds}+1 / 3^{\text {rd }}\right)$. Source: United States (1991, table B-3, col. 2, p. 290, table B-107, p. 408).

Sources: See text. 


\section{University of Oxford Discussion Papers in Economic and Social History}

1 Hans-Joachim Voth and Tim Leunig, Did Smallpox Reduce Height? Stature and the Standard of Living in London, 1770-1873 (Nov. 1995)

2 Liam Brunt, Turning Water into Wine - New Methods of Calculating Farm Output and New Insights into Rising Crop Yields during the Agricultural Revolution (Dec. 1995)

3 Avner Offer, Between the Gift and the Market: the Economy of Regard (Jan. 1996)

4 Philip Grover, The Stroudwater Canal Company and its Role in the Mechanisation of the Gloucestershire Woollen Industry, 1779-1840 (March 1996)

5 Paul A. David, Real Income and Economic Welfare Growth in the Early Republic or, Another Try at Getting the American Story Straight (March 1996)

6 Hans-Joachim Voth, How Long was the Working Day in London in the 1750s? Evidence from the Courtroom (April 1996)

7 James Foreman-Peck, 'Technological Lock-in' and the Power Source for the Motor Car (May 1996)

8 Hans-Joachim Voth, Labour Supply Decisions and Consumer Durables During the Industrial Revolution (June 1996)

9 Charles Feinstein, Conjectures and Contrivances: Economic Growth and the Standard of Living in Britain During the Industrial Revolution (July 1996)

10 Wayne Graham, The Randlord's Bubble: South African Gold Mines and Stock Market Manipulation (August 1996)

11 Avner Offer, The American Automobile Frenzy of the 1950s (December 1996)

12 David M. Engstrom, The Economic Determinants of Ethnic Segregation in Post-War Britain (January 1997)

13 Norbert Paddags, The German Railways - The Economic and Political Feasibility of Fiscal Reforms During the Inflation of the Early 1920s (February 1997)

14 Cristiano A. Ristuccia, 1935 Sanctions against Italy: Would Coal and Crude Oil have made a Difference? (March 1997)

15 Tom Nicholas, Businessmen and Land Purchase in Late Nineteenth Century England (April 1997)

16 Ed Butchart, Unemployment and Non-Employment in Interwar Britain (May 1997)

17 Ilana Krausman Ben-Amos, Human Bonding: Parents and their Offspring in Early Modern England (June 1997) 
18 Dan H. Andersen and Hans-Joachim Voth, The Grapes of War: Neutrality and Mediterranean Shipping under the Danish Flag, 1750-1802 (September 1997)

19 Liam Brunt, Nature or Nurture? Explaining English Wheat Yields in the Agricultural Revolution (Oct. 1997)

20 Paul A. David, Path Dependence and the Quest for Historical Economics: One More Chorus of the Ballad of QWERTY (Nov. 1997)

21 Hans-Joachim Voth, Time and Work in Eighteenth-Century London (Dec. 1997)

22 Tim Leunig, New Answers to Old Questions: Transport Costs and The Slow Adoption of Ring Spinning in Lancashire (Feb. 1998)

23 Paul A. David, From Keeping 'Nature's Secrets' to the Institutionalization of 'Open Science' (July 2001)

24 Federico Varese and Meir Yaish, Altruism: The Importance of Being Asked. The Rescue of Jews in Nazi Europe (May 1998)

25 Avner Offer, Epidemics of Abundance: Overeating and Slimming in the USA and Britain since the 1950s (Nov. 1998)

26 David Stead, An Arduous and Unprofitable Undertaking: The Enclosure of Stanton Harcourt, Oxfordshire (November 1998)

27 Oliver Grant, The Diffusion of the Herringbone Parlour: A Case Study in the History of Agricultural Technology (December 1998)

28 Antonia Taddei, London Clubs in the Late Nineteenth Century (April 1999)

29 Liam Brunt, Estimating English Wheat Production in the Industrial Revolution (June 1999)

30 Matthew Braham, Volunteers for Development: A Test of the PostMaterialism Hypothesis in Britain, c.1965-1987 (June 1999)

31 Paul A. David and Gavin Wright, General Purpose Technologies and Surges in Productivity: Historical Reflections on the Future of the ICT Revolution (September 1999)

32 Liam Brunt, An Arbitrage Model of Crop Rotation (September 1999)

33 Paul A. David and Gavin Wright, Early Twentieth Century Productivity Growth Dynamics: An Inquiry into the Economic History of 'Our Ignorance' (October 1999)

34 Avner Offer, Economic Welfare Measurements and Human Well-Being (January 2000). Rev. version, March 2000.

35 Liam Brunt, 'Where there's Muck, There's Brass.' The Market for Manure in the Industrial Revolution (February 2000).

36 Alasdair Crockett, Variations in Churchgoing Rates in England in 1851: Supply-Side Deficiency or Demand-Led Decline? (August 2000). 
37 Martin West, State Intervention in English Education, 1833-1891: A Public Goods and Agency Approach (October 2000).

38 George Speight, Who Bought the Inter-War Semi? The Socio-Economic Characteristics of New-House Buyers in the 1930s (December 2000)

39 Peter Temin, A Market Economy in the Early Roman Empire (March 2001)

40 Michael Biggs, Positive Feedback in Collective Mobilization: The American Strike Wave of 1886 (April 2001)

41 Charles H. Feinstein and Mark Thomas, A Plea for Errors (July 2001)

42 Walter Eltis, Lord Overstone and the Establishment of British NineteenthCentury Monetary Orthodoxy (December 2001)

43 A. B. Atkinson, Top Incomes in the United Kingdom over the Twentieth Century (February 2002)

44 Avner Offer, Why has the Public Sector Grown so Large in Market Societies? The Political Economy of Prudence in the UK, c.1870-2000 (March 2002)

45 Natàlia Mora Sitjà, Labour and Wages in Pre-Industrial Catalonia (May 2002)

46 Elaine S. Tan, 'The Bull is Half the Herd': Property Rights and Enclosures in England, 1750-1850 (June 2002)

47 Oliver Wavell Grant, Productivity in German Agriculture: Estimates of Agricultural Productivity from Regional Accounts for 21 German Regions: 1880/4, 1893/7 and 1905/9 (August 2002)

48 Oliver Wavell Grant, Does Industrialization Push up Inequality? New Evidence on the Kuznets Cure from Nineteenth-Century Prussian Tax Statistics (September 2002)

49 Alexandre Debs, The Source of Walras's Idealist Bias: A Review of Koppl's Solution to the Walras Paradox (January 2003)

50 Robert Dryburgh, 'Individual, Illegal, and Unjust Purposes': Overseers, Incentives, and the Old Poor Law in Bolton, 1820-1837 (March 2003)

51 David R. Stead, Risk and Risk Management in English Agriculture, c.17501850 (October 2003)

52. Pablo Astorga, Ame R. Bergés, and Valpy FitzGerald, Productivity Growth in Latin America during the Twentieth Century (December 2003)

53. Teresa da Silva Lopes, Evolution of Corporate Governance in Global Industries: The Case of Multinationals in Alcoholic Beverages (February 2004)

54 Pablo Astorga, Ame R. Bergés, and Valpy FitzGerald, The Standard of Living in Latin America during the Twentieth Century (March 2004)

55 Regina Grafe, Popish Habits vs. Nutritional Need: Fasting and Fish Consumption in Iberia in the Early Modern Period (May 2004) 
56 Nicholas Dimsdale: Unemployment and Real Wages in Weimar Germany (October 2004)

57 Pablo Astorga, Ame R. Bergés, and Valpy FitzGerald, The Standard of Living in Latin America During the Twentieth Century (March 2005)

58 Richard H. Steckel, Fluctuations in a Dreadful Childhood: Synthetic Longitudinal Height Data, Relative Prices, and Weather in the Short-Term Health of American Slaves (April 2005)

59 Federico Varese, How Mafias Migrate: The Case of the 'Ndrangheta in Northern Italy (July 2005)

60 Avner Offer, The Markup For Lemons: Quality And Uncertainty in American and British Used-Car Markets c.1953-1973 (September 2005, reprinted October 2007)

61 Natalia Mora-Sitja, Exploring Changes in Earnings Inequality during Industrialization: Barcelona, 1856-1905 (April 2006)

62 Camilla Brautaset and Regina Grafe, The Quiet Transport Revolution: Returns to Scale, Scope and Network Density in Norway's Nineteenth-Century Sailing Fleet (June 2006)

63 Mohammad Niaz Asadullah, Educational Disparity in East and West Pakistan, 1947-71: Was East Pakistan Discriminated Against? (July 2006)

64 Jane Humphries, 'Because they are too menny...' Children, Mothers, and Fertility Decline: The Evidence from Working-Class Autobiographies of the Eighteenth and Nineteenth Centuries (September 2006)

65 M. A. Irigoin and R. Grafe, Bargaining for Absolutism: A Spanish Path to Nation State and Empire Building (November 2006)

66 Jane Humphries and Tim Leunig, Cities, market integration and going to sea: stunting and the standard of living in early nineteenth-century England and Wales (March 2007) 


\title{
University of Oxford Discussion Papers in Economic and Social History
}

are edited by:

Jane Humphries

All Souls College, Oxford, OX1 4AL

\author{
Avner Offer \\ All Souls College, Oxford, OX1 4AL
}

Papers may be downloaded from http://www.nuff.ox.ac.uk/Economics/History/ 